\title{
Composition of biofouling communities on suspended oyster cultures: an in situ study of their interactions with the water column
}

\author{
N. Mazouni ${ }^{1, *}$, J.-C. Gaertner ${ }^{2}$, J.-M. Deslous-Paoli ${ }^{1}$ \\ ${ }^{1}$ IFREMER, Laboratoire DEL - Ecologie, BP 171, 34203 Sète-cedex, France \\ ${ }^{2}$ Centre d'Océanologie de Marseille, Fédération de Recherche 6106, Rue de la Batterie des Lions, 13007 Marseille, France
}

\begin{abstract}
This study was based on in situ experiments conducted in a shellfish lagoon (Thau, France) to determine the interactions between suspended oyster Crassostrea gigas Thunberg cultures and their environment at a seasonal scale. Three groups of descriptors were considered simultaneously during the course of the study: the taxonomic composition of an oyster culture unit (OCU), the nutrient and oxygen exchanges at the OCU-water interface (fluxes) and the water-column characteristics (water). We used a multiple factorial analysis (MFA) to assess in a single reference frame: (1) the seasonal organisation of the taxonomic groups which compose the OCU and (2) the interactions between this multispecific assemblage and the water column. We found strong seasonal variability in the OCU composition and the OCU interactions with the water column. Taxonomic richness of the biofouling was at a maximum in spring and minimum in August after a bottom anoxia. Among biofouling species, ascidians always constituted the dominant group. The annual pattern of coexistence observed between ascidians and oysters might be explained by resource partitioning, and also by a beneficial trophic interaction between these 2 groups. The structure of the OCU was based on a complex system of interactions, particularly in spring. During this season, the development on the OCU of macrofauna of soft substratum such as polychaetes reflected the presence of a suspended sediment compartment. The influence of the OCU on the water column was maximum in summer and minimum in winter. In the shellfish zone, the OCU plays a central role in nutrient renewal, particularly in summer when benthic fluxes are insufficient to satisfy phytoplankton nitrogen requirements. We estimate that the multispecific assemblages occurring on the oyster ropes (oysters and biofouling) have a potential annual DIN production of $2 \times 10^{7} \mathrm{~mol} \mathrm{yr}^{-1}$, and thus oyster cultures could have a determining influence on nitrogen recycling in the water column in the Thau lagoon.
\end{abstract}

KEY WORDS: Oyster culture $\cdot$ Biofouling $\cdot$ Multicompartment approach $\cdot$ Fluxes $\cdot$ Ascidians

\section{INTRODUCTION}

In enclosed and semi-enclosed aquatic ecosystems the development of shellfish farming alters both the physical and chemical characteristics of the water column (Cloern 1982, Murphy \& Kremer 1985, Dame et al. 1989, 1991, Dame \& Libes 1993, Mazouni et al. 1996) and enhances the fluxes of the organic matter toward

*Present address: CEPRALMAR, Rue de la République, 34000 Montpellier, France. E-mail: nabila@mazouni.com the sediments (Boynton et al. 1980, Dame et al. 1989, Sornin et al. 1990). Furthermore, the physiological activities of the cultivated bivalves often induce the formation of a chlorophyll sink (Jarry et al. 1990) and can also control the abundance of the phytoplankton populations (Cloern 1982, Alpine \& Cloern 1992).

This direct impact of cultivated species is reinforced by the development of biofouling communities (David 1970, Agius et al. 1977, Arakawa 1990, Dalby \& Young 1993, Mazouni 1995, Lamy 1996) which colonize the oyster shells particularly when farming structures are constantly submerged. Several studies on the physio- 
logy of some epifaunal species such as ascidians (David 1970, Fiala-Médioni 1974, 1978, Lesser et al. 1992, Riisgård et al. 1995, Petersen et al. 1997), or sponges (Reiswig 1972, Stuart \& Klumpp 1984, Lesser et al. 1992), have shown their potential influence on the water column and on the species they overgrow. However, the influence of shellfish cultures on their environment has been mostly described by considering only the cultivated species (Murphy \& Kremer 1985, Prins \& Smaal 1990, Dame et al. 1991, Dame 1993, Dame \& Libes 1993, Hatcher et al. 1994) rather than the whole assemblages (oyster and biofouling species).

In this context, and in order to provide a more realistic picture of the impact of oyster cultures on the water column, we propose in the present paper a new approach based on the consideration of oyster-cultures as a whole assemblage (oyster and biofouling). The study has been carried out in Thau lagoon where Japanese oysters Crassostrea gigas Thunberg are reared on constantly submerged long-lines on which the biomass of biofouling communities can comprise 2.7 to $14 \mathrm{~kg}$ per line (David 1970, Lamy 1996). The aims of the study were to determine (1) the seasonal structural patterns of an oyster-culture assemblage (taxonomic richness, dominance), and

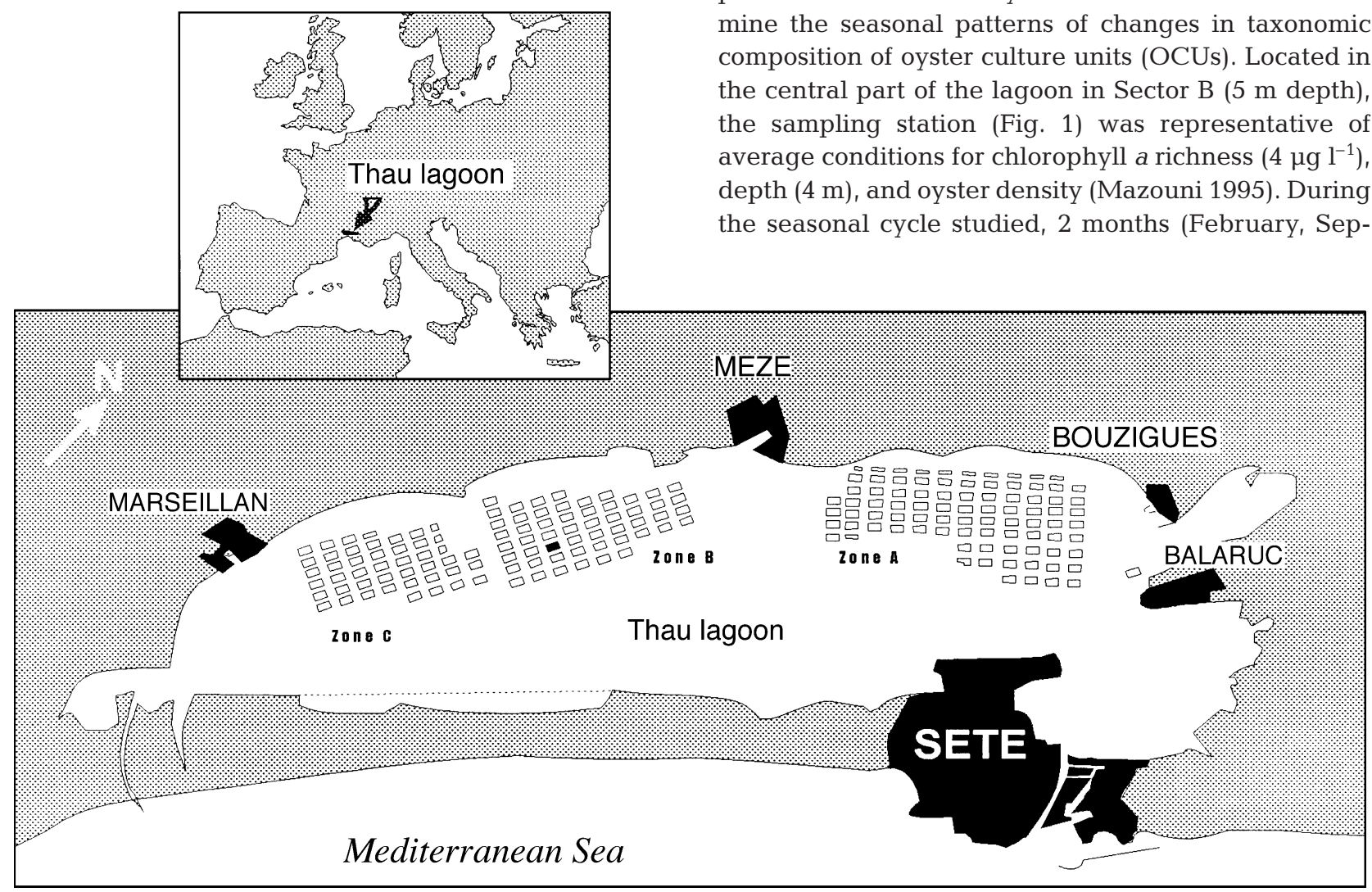

Fig. 1. Location of Thau Lagoon. Zones A, B, C: oyster Crassostrea gigas areas; open squares: oyster frames; black square: sampling

station
(2) the interactions between the taxonomic composition of oyster culture units (OCU) and the water column. To this end, we performed a multicompartment approach based on the simultaneous temporal monitoring of the taxonomic composition of the OCUs, the exchanges at the OCU-water interface ('fluxes') and the characteristics of the water column ('water'). Our main questions were: (1) Which factors control the biofouling development and the taxonomic composition of an OCU? (2) How does the whole suspended community affect the surrounding area?

\section{MATERIALS AND METHODS}

Study site. Thau lagoon is a shallow marine ecosystem, located on the French southwest Mediterranean coast (Fig. 1). In this 7500 ha basin, depth is about $4 \mathrm{~m}$ on average, and water renewal is weak, from 3 to 4 mo (Millet 1989). Since 1977, a semi-intensive oyster-farming industry has been developed. The oyster farms provide $90 \%$ of the French Mediterranean oyster yield, which represents $10 \%$ of the total French production of oysters.

Monthly monitoring of the OCU composition was performed from January to December 1992 to determine the seasonal patterns of changes in taxonomic composition of oyster culture units (OCUs). Located in the central part of the lagoon in Sector B (5 m depth), average conditions for chlorophyll a richness $\left(4 \mathrm{\mu g} \mathrm{l}^{-1}\right)$, depth (4 m), and oyster density (Mazouni 1995). During the seasonal cycle studied, 2 months (February, Sep- 


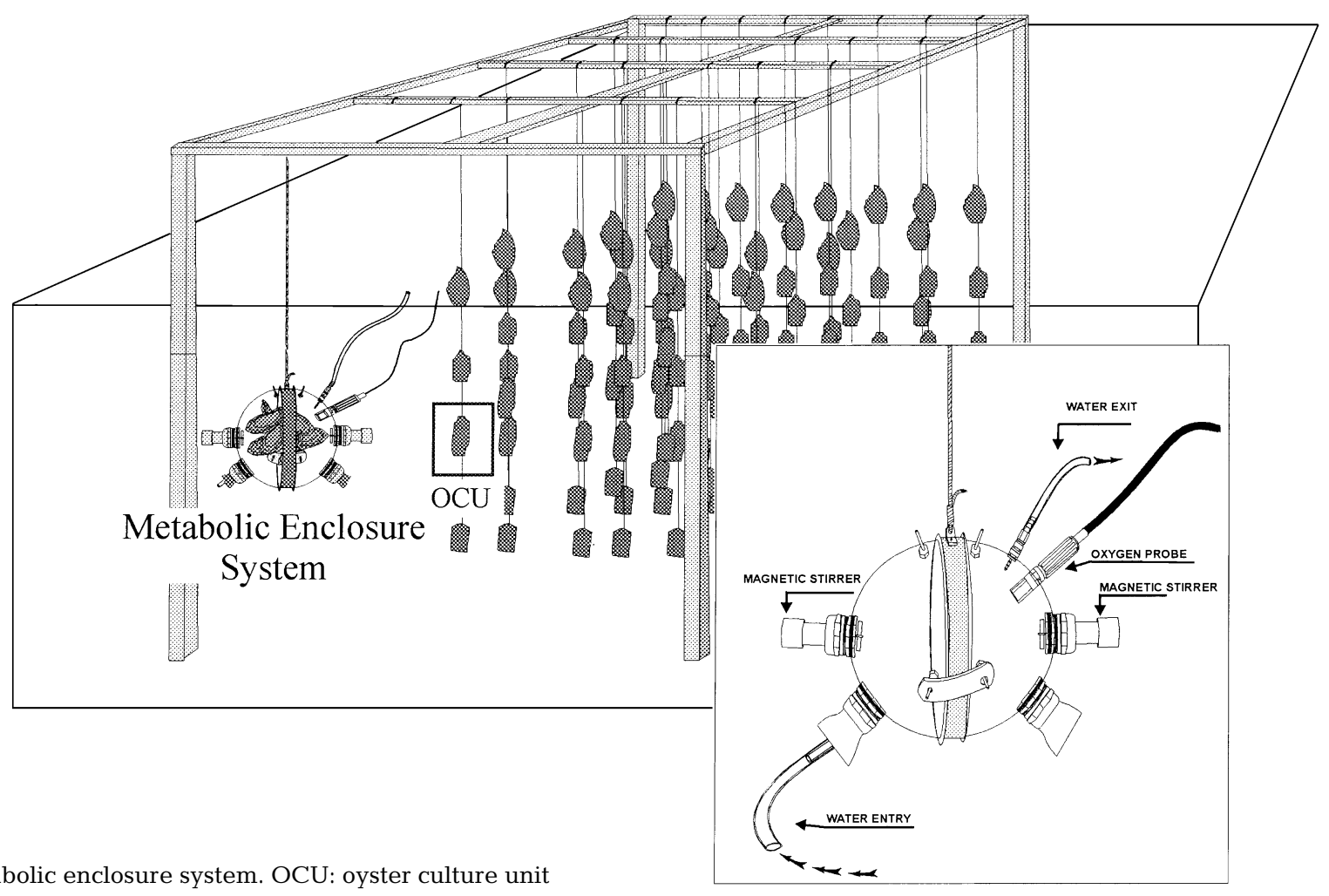

Fig. 2. Metabolic enclosure system. OCU: oyster culture unit

enclosure system (MES) (Mazouni et al. 1998). This system consists of 2 transparent metacrylate hemispheres fitted together with a plastic (PVC) ring, with a total volume of 35.71 (Fig. 2). Each metabolic enclosure contained an OCU. The MES was used in flow-through conditions or in incubation, in order to estimate, respectively, the filtration rate of the OCU and the oxygen and nutrient fluxes. The water was circulated by means of a peristaltic pump connected to each metabolic enclosure, and 2 magnetic stirrers prevented stratification of the water.

All water inlets were centralised to obtain homogeneous conditions for each MES. Water was sampled (3 replicates) at the entrance and exit of each MES to measure the influence of the OCU on in vivo fluorescence. Then we stopped the pump and closed the system for use in incubation to estimate oxygen and nutrient fluxes. Water (100 ml) was sampled in each MES every $30 \mathrm{~min}$ to estimate changes in nutrient concentrations during incubation. Oxygen concentrations were monitored with an oxygen probe, and recorded throughout the experiment. Fluxes are defined as the slope of the linear regression between concentration of the corresponding element and the time of the experiment (incubation). The filtration (FIL) of the OCU was calculated on the basis of changes in in vivo fluorescence. The filtration rate of the OCU was expressed in $1 \mathrm{~h}^{-1}$ and calculated as: 
$\mathrm{FIL}=[(\mathrm{INIT}-\mathrm{FINAL}) / \mathrm{INIT}] \cdot R$

where INIT = initial in vivo fluorescence in the water column, FINAL = final in vivo fluorescence in the water after being subjected to filtration by the OCU, and $R=$ flow rate in the metabolic enclosures $\left(1 \mathrm{~h}^{-1}\right)$, which varies between 30 and $120 \mathrm{l} \mathrm{h}^{-1}$ (according to water temperature) to achieve a total particle uptake of $<30 \%$.

Data used. The variables measured were divided into 3 groups (Table 1). The structuring of variables into groups (OCU, fluxes, water) allowed the simultaneous study of different components of the ecosystem. In Group 1, taxonomic groups were expressed as percentages of total biomass of the OCUs to describe the composition of the OCUs. Group 2 was representative of the direct impact of the shellfish farming on the environment (fluxes); and Group 3 was characteristic of the conditions prevailing in the water column (water). For the OCU group, we tested variability between 3 replicates measured on the same date, and found it significantly lower than the monthly variability of the OCU (ANOVA, $\mathrm{p} \leq 0.05$ ). So, for each month, the OCU composition is presented as an average of the 3 replicates used in our experiments.

Data analysis. The temporal monitoring of interactions between the OCU and its environment required the combined analysis of the 3 groups of variables considered in our work (OCU, fluxes, water). Multivariate analyses constitute a useful tool to study the interactions between several compartments of an ecosystem (Ter Braak 1987, Dolédec \& Chessel 1994). However, the structuring of variables into groups (OCU, water, fluxes) limits the use of standard multivariate analyses, which would not be able to balance the effect of all groups. In the present study, the temporal monitoring of interactions between the OCU and its environment required the combined analysis of the 3 groups of variables considered. To this end, we needed a method able (1) to coordinate the analysis of each group within a rigorous and reproducible framework, and (2) to provide a clear representation of their associations. Multiple factorial analysis (MFA, Escofier \& Pagès 1994) may well meet this requirement. The first step of the MFA consists of performing a separate principal component analysis (PCA) for each group of quantitative variables. In the second step, each group of the entire matrix is weighted by the inverse of the first eigenvalue of its separate analysis to balance inertia between the different groups and thus balance their influences. This method made it possible to consider all the groups on an equal basis. The third step is a global PCA (i.e. a PCA of the entire weighted matrix) analysing in single factorial space the patterns of different groups of variables. Assessment of the correlation between the global scatter (defined by all the variables) and the partial (defined by each group) indicates whether the structure shown by each axis of the MFA is common to several groups or if it is specific to one of them. So the MFA allowed us to study both the seasonal organisation patterns of the OCU and the interactions between it and its environment. For further details on the statistical models on which the MFA is based see Escofier \& Pagès (1994), Haury et al. (1995) and Chessel \& Hanafi (1996). The MFA was performed with ADE-4 software (Thioulouse et al. 1996), available in freeware distribution on internet (http://biom3.univ-lyon1.fr/ADE-4/ADE-4.html).

Table 1. Types and units of variables used in multiple factorial analysis. $\mathrm{F}_{\text {ammonium, }}, \mathrm{F}_{\text {nitrate, }}, \mathrm{F}_{\text {phosphate, }} \mathrm{F}_{\text {oxygen }}: \mathrm{NH}_{4}, \mathrm{NO}_{2}-\mathrm{NO}_{3}, \mathrm{PO}_{4}$, $\mathrm{O}_{2}$ fluxes, respectively; FIL: clearance rate. February and September not sampled (technical problems). Positive values of fluxes indicate production, negative values consumption by oyster culture unit (OCU); positive value of oxygen fuxes in November was linked to the presence of macroalgae on the OCU and to the strong agitation of the water around the experimental system

\begin{tabular}{|c|c|c|c|c|c|c|c|c|c|c|c|}
\hline Variable & & Mar & Apr & May & Jun & Jul & Aug & Oct & Nov & Dec & Jan \\
\hline \multicolumn{12}{|c|}{ Fluxes (Group 2) } \\
\hline $\mathrm{F}_{\text {ammonium }}$ & $\left(\mu \mathrm{mol} \mathrm{h}{ }^{-1} \mathrm{OCU}^{-1}\right)$ & 26.12 & 41.46 & 72.47 & 72.69 & 96.84 & 51.46 & 67.75 & 31.31 & 22.09 & 5.9 \\
\hline $\mathrm{F}_{\text {nitrate }}$ & $\left(\mu \mathrm{mol} \mathrm{h}{ }^{-1} \mathrm{OCU}^{-1}\right.$ & 7.34 & 5.77 & 22.81 & 13.54 & 29.69 & 63.13 & 22.58 & 8 & 15.9 & 0.07 \\
\hline $\mathrm{F}_{\text {phosphate }}$ & $\left(\mu \mathrm{mol} \mathrm{h}{ }^{-1} \mathrm{OCU}^{-1}\right)$ & 3.16 & 13.23 & 56.21 & 9.89 & 16.45 & 4.8 & 5.98 & 89.71 & -0.37 & -0.10 \\
\hline $\mathrm{F}_{\text {oxygen }}$ & $\left(\mu \mathrm{mol} \mathrm{h}{ }^{-1} \mathrm{OCU}^{-1}\right)$ & -156.19 & -219.41 & -247.37 & -283.72 & -394.09 & -187.98 & -143.81 & 374.26 & -137.94 & 0 \\
\hline FIL & $\left(\mathrm{l} \mathrm{h}^{-1} \mathrm{OCU}^{-1}\right)$ & 12.3 & 20.57 & 46.92 & 32.95 & 62.38 & 65.94 & 32.3 & 14.25 & 15.87 & - \\
\hline \multicolumn{12}{|c|}{ Water (Group 3) } \\
\hline $\mathrm{T}$ & $\left({ }^{\circ} \mathrm{C}\right)$ & 10 & 12.5 & 21.5 & 19 & 22 & 26 & 14 & 12 & 8 & 3.7 \\
\hline$\left[\mathrm{O}_{2}\right]$ & $\left(\mu \mathrm{mol} \mathrm{l} \mathrm{l}^{-1}\right)$ & 8.8 & 7.7 & 6.8 & 5.7 & 5.2 & 4.5 & 6.35 & 7.6 & 8.3 & 8.9 \\
\hline$\left[\mathrm{NH}_{4}\right]$ & $\left(\mu \mathrm{mol} \mathrm{l} \mathrm{l}^{-1}\right)$ & 0.61 & 0.15 & 0.08 & 1 & 0.24 & 0.68 & 8.67 & 2.59 & 2.47 & 0.87 \\
\hline$\left[\mathrm{NO}_{2}-\mathrm{NO}\right.$ & ] $\left(\mu \mathrm{mol} \mathrm{l} \mathrm{l}^{-1}\right)$ & 0.24 & 0.07 & 0.27 & 0.29 & 0.13 & 0.62 & 2.98 & 3.57 & 1.89 & 0.46 \\
\hline$\left[\mathrm{PO}_{4}\right]$ & $\left(\mu \mathrm{mol} \mathrm{l} \mathrm{l}^{-1}\right)$ & 0.22 & 0.31 & 0.98 & 1.34 & 0.92 & 3.3 & 1.21 & 0.77 & 0.43 & 0.39 \\
\hline Salinity $^{2}$ & (psu) & 36.5 & & & & 38.8 & & 35.8 & & 36 & 8.9 \\
\hline Chl a & $\left(\mu g l^{-1}\right)$ & 0.7 & & & & 0.9 & & 0.6 & & 0.5 & \\
\hline \multicolumn{12}{|c|}{${ }^{\mathrm{a}} \mathrm{A}$. Vaquer (unpubl. data) } \\
\hline
\end{tabular}




\section{RESULTS}

In this study, on Crassostrea gigas OCUs, the MFA higlighted a strong seasonal structuring of the 3 groups studied. In Table 2, the high correlation coefficients indicate that the 2 first axes of the MFA were common to all groups (OCUs, fluxes, water). So, as they provide a good representation of the seasonal variation in the components studied, only the first 2 factorial axes of the MFA are presented. They accounted for $64.5 \%$ of the total inertia and revealed a 2-fold opposition between seasons (Fig. 3). The projection of samples (months) onto the first factorial plane showed that the first axis (36\%) revealed an opposition between summer (June, July, August) and winter (December, January) mainly due to a temperature gradient (Fig. 4) that ranged from 4 (January) to $25^{\circ} \mathrm{C}$ (August). On the second axis, the opposition between spring and autumn (independent of the temperature gradient) accounted for an important part of the total variability $(28.5 \%)$. Taxonomic diversity of the biofouling and nutrient concentrations in the water column distinguished between these 2 seasons: spring was characterised by high taxonomic diversity in the OCUs and high nitrogen concentrations in the water column, whereas in autumn the biofouling community was mainly composed of ascidians ( $75 \%$ of total biomass of the OCUs: Table 1 ).

\section{Structural pattern of OCUs}

The projection of variables onto the first factorial plane of the MFA (Fig. 5) showed that on Axis 1 sponges and algae were opposed to oysters, whereas on Axis 2 the abundance of ascidians opposed the presence of polychaetes. Among the epifaunal taxonomic groups, ascidians (Ciona intestinalis, Phallusia mammillata, Botryllus sp.) were dominant in the OCU assemblage, but their percentage showed a seasonal pattern. However, their presence was independent of water temperature, as they were found when water temperature was very low $\left(4^{\circ} \mathrm{C}\right)$ in January as well as when it was high $\left(23\right.$ to $\left.25^{\circ} \mathrm{C}\right)$ in summer (Fig. 6). In August (5 wk after a bottom anoxia event), only young ascidians were present on the oyster shells, their biomass accounting for $84 \%$ of the total bio-

Table 2. Correlation coefficients between each of first 2 factorial axes of multiple factorial analysis and projection of each group of variables. OCU: oyster culture units

\begin{tabular}{|lccc|}
\hline Axis & OCUs & Fluxes & Water \\
\hline 1 & 85.9 & 95.1 & 97.7 \\
2 & 95.0 & 71.9 & 94.4 \\
\hline
\end{tabular}

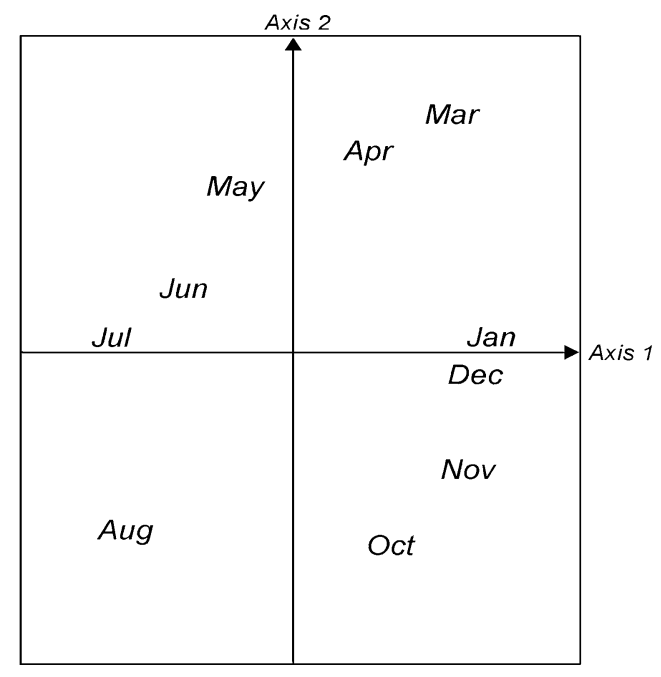

Fig. 3. Projections on first 2 factorial axes of the multiple factorial analysis of each sample (months)

mass of the OCU. From March to July, increased taxonomic richness occurred, with the development of bryozoans, sponges, polychaetes and algae (Fig. 6). Polychaetes Capitella capitata were present from March to July and in December.

\section{Interactions between OCUs and their environment}

On the first axis of the MFA, the projected variables of the fluxes group were distributed according to their intensity, which was maximum in summer, except in the case of phosphate fluxes (Fig. 5). For these, their central positioning on the first factorial plane of the MFA showed their relative independence with regard both to temperature gradient (Axis 1) and species diversity and nutrient concentrations (Axis 2). The very close proximity of January and December on the first factorial plane of the MFA (Fig. 3) indicates that the

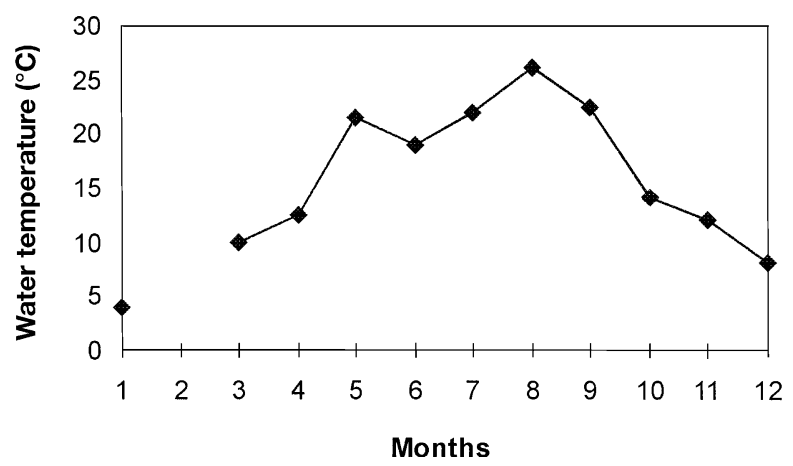

Fig. 4. Seasonal changes in water temperature 


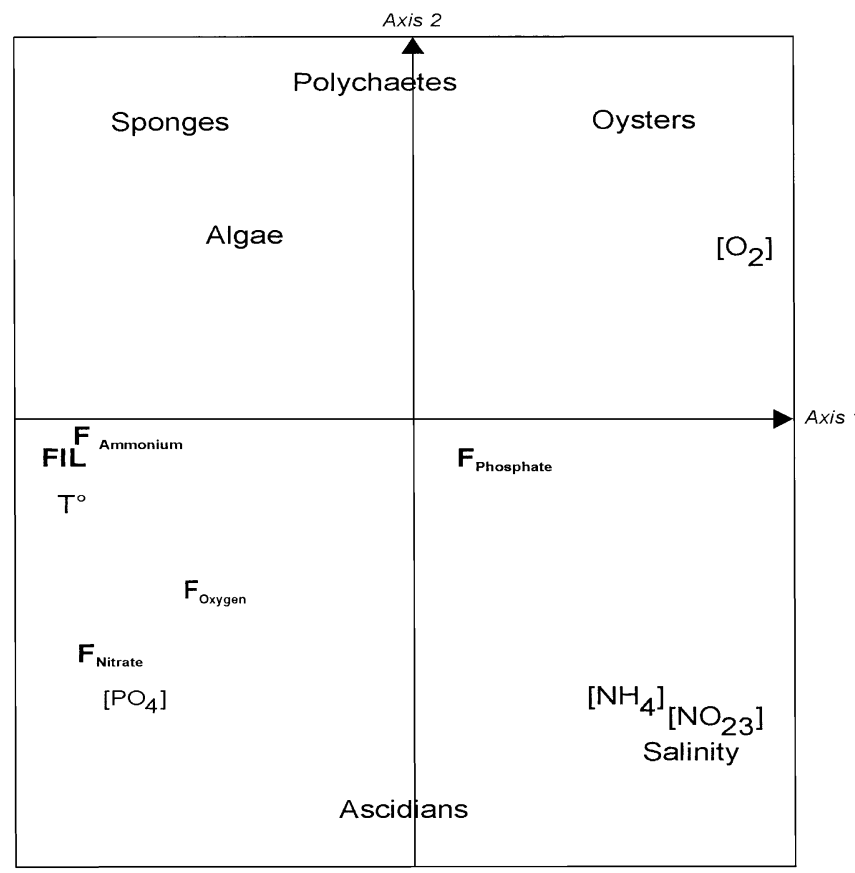

Fig. 5. Projection on first 2 factorial axes of multiple factorial analysis of all variables. Details of variables in Table 2

winter period was homogeneous for all 3 groups. It was characterised by high oxygen concentration $(8.6 \mu \mathrm{mol}$ $\mathrm{l}^{-1}$ ) and very low flux intensity. Conversely, in summer (June to August), the OCUs had the greatest impact on the water column, as fluxes were maximum. Moreover, although the projections of July and August of Fig. 5 are close on the first axis, they are markedly distinct on the second axis. Flux intensity and clearance rate were important in both these months, but species composition between OCUs differed completely (Fig. 3). This shows that summer was composed of 2 periods: the first (June to July) during which the biofouling community was multispecific, the second (August) during which it was monospecific. During spring (March to
May) and autumn (September to November), the fluxes (nutrients and oxygen) and filtration rate of the OCUs were weak, indicating that oyster cultures had a reduced influence on the water column. The water-column characteristics differed notably between these 2 seasons, with high levels of nutrient concentrations in autumn and low levels in spring (Figs. 5 \& 6, Table 1).

\section{DISCUSSION}

The MFA gave an overall picture of both the structural patterns of the oyster-culture assemblages and the interactions between the OCUs and the water column on a seasonal scale. On the OCUs, the taxonomic composition of the biofouling community showed strong seasonal variability, but ascidians were always dominant. In regard to interactions between the OCUs and the water column, water temperature greatly influenced both the taxonomic diversity of the OCUs and the impact of the cultivated assemblages on the water column.

\section{Seasonal patterns in OCU structure}

On the oyster shells, the taxonomic richness of the biofouling community was maximum in spring and minimum in winter. In spring, the colonization of the substratum was enhanced by the great abundance of larval forms during what is a period of breeding for many organisms (Fiala-Médioni 1974, Petersen \& Svane 1995, Lamy 1996). While oyster shells constitute hard substrata for biofouling species, in spring we found that macrofaunal soft-substratum communities such as polychaetes were abundant on the OCUs. One explanation of this unexpected result could be the activity of biofouling organisms. Several authors have pointed out that activities of biofouling organisms (especially of ascidians, which produce large amounts of biodeposits; Fiala-Médioni 1974) can lead to accu-
Fig. 6. Seasonal changes in taxonomic group composition of an oyster culture unit. Calculated on basis of total dry weight of assemblage

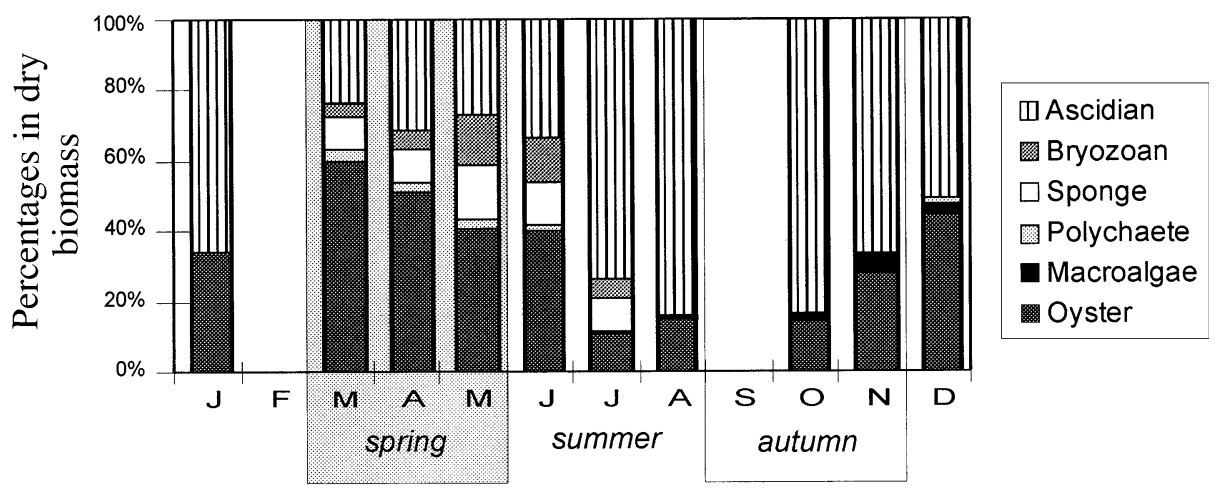


mulation of organic matter along the oyster ropes (Agius et al. 1977, Arakawa 1990) and thus to modifications to the substratum (Dean \& Hurd 1980). In the OCUs of the present study, the polychaete Capitella capitata developed, an organism that is a biological indicator of an environment with high organic content (Reish 1955, Grassle \& Grassle 1974). This result showed that in Thau lagoon, oyster cultures are responsible for the formation of a sediment compartment suspended in the water column. The structure of the OCUs was thus based on a complex system of interactions in which several compartments (macrofauna of hard and soft substrata, sediment) and trophic levels (primary producers, filter-feeders, deposit-feeders) were represented. Possibly this accumulation of organic matter along the oyster ropes could partly explain the weak enrichment in organic matter recorded in the underlying sediment of Thau lagoon (Mazouni et al. 1996), compared to that of most shellfish-farming areas (Sornin et al. 1987, Grenz et al. 1990, Smaal 1991).

While spring was characterized by high species diversity, we recorded a low level in July. During this month, we previously evidenced the presence of bottom anoxia and its impact on the water-sediment interface (Mazouni et al. 1996). The expansion of this phenomenon into the water column might be responsible for the high mortality on the OCUs, and partly explain the strong decrease in biofouling diversity observed in July. During anoxia, oysters may survive due to their ability to adapt to anaerobic conditions (Shumway 1981, Riva \& Massé 1985). Conversely, ascidians, which are highly sensitive to this kind of perturbation (Osman et al. 1989), disappeared completely. The subsequent return to oxic conditions allowed new development of epifauna on the substratum (oyster shells). The ability of tunicates to again colonize the substratum as early settlers (Branch 1984, Lamy 1996) was confirmed by the abundant presence of young ascidians 5 wk after the anoxia event (August).

Our results also evidenced the coexistence of oysters and ascidians during the whole seasonal cycle studied. Coexistence between these 2 suspension-feeders has been previously described by Dalby \& Young (1993), who tested the tolerance of oysters to ascidian overgrowth in Florida, and by Petersen et al. (1997), who compared the growth rate of mussels and ascidians in eelgrass meadows. However, ascidians are generally considered as trophic competitors that could limit and/or retard oyster development (Jackson 1983, Stuart \& Klumpp 1984) by exerting high grazing pressure on the phytoplankton (Riisgård et al. 1995). In the Thau lagoon, picophytoplankton $(<1 \mu \mathrm{m})$, which represents 73 to $93 \%$ of the total phytoplankton cells detected by flow cytometry and $20 \%$ of the whole phytoplankton biomass (Courties et al. 1994, Vaquer et al. 1997), is consumed abundantly by the OCUs (Mazouni et al. 1992, Mazouni 1995). Given the fact that oysters only feed efficiently on larger particles (Kuzuki 1977, Shumway et al. 1985, Outin 1990), picophytoplankton could constitute a major food resource for ascidians, which are known to take up small particles efficiently (Fiala-Médioni 1974, Monniot 1979, Jørgensen et al. 1984). The high level of abundance of picophytoplankton cells in the water column and the lack of any particle selection by ascidians (Petersen et al. 1997) could also favour resource-partitioning between the 2 species. This food-resource partitioning might limit the trophic competition expected between these 2 populations of filter-feeders (Branch 1984) and explain their coexistence in the Thau lagoon.

However, in accordance with Arakawa's (1990) concept that 'a beneficial effect a certain amount of fouling could have on the development of the oysters during cultivation', trophic interactions between oysters and ascidians might not be limited to this kind of resource-partitioning. These tunicates, which filter large amounts of water (Jørgensen \& Goldberg 1953, Fiala-Médioni 1978, Monniot 1979, Randlov \& Riisgard 1979), trap particles with a continuous mucus sheet (Jørgensen \& Goldberg 1953, Jørgensen 1966) and produce large quantities of biodeposits (Fiala-Médioni 1974). The presence in their faeces and pseudofaeces of intact algae embedded in mucus sheets (FialaMédioni 1973) shows the potential influence ascidians could have on oyster particle-uptake. These released aggregates of picophytoplankton or other small particles are in a size range which could subsequently be available as a food source for the oysters. Our assumption of positive trophic interactions between these 2 groups appears to be in accordance with (1) in situ observations of shellfish farmers who consider ascidian development on the oyster ropes as predictive of a good harvest, and (2) the rapid oyster growth rate recorded in this lagoon, which is the fastest of all French shellfish-farming areas (Anonymous 1994). Nevertheless, at this stage, further experiments are needed to test this hypothesis, and they will constitute the next step of our work.

\section{Interactions between OCUs and their environment}

In the present work, fluxes showed a strong pattern of seasonal structuring. With the exception of phosphate, high fluxes were correlated to high temperature and to high species diversity. In summer, the water temperature stimulated the activity of the organisms present on the OCUs. This positive relationship with temperature has been previously described in connection with oxygen uptake by the oysters (Shumway 1981, 
Bougrier et al. 1995) and with nitrogen production (Dame et al. 1989, Zuburg \& Smaal 1993). The very low fluxes in winter could also be explained by water temperature, which reached an exceptionally low level in January $1992\left(4^{\circ} \mathrm{C}\right)$. This thermal stress induced dormancy in the organisms and the high mortality rate observed in the biofouling populations and the cultivated oysters. Among the biofouling species, only ascidians (especially Ciona intestinalis) were still present on the oyster shells. This species, also found in Danish fjords (Petersen \& Svane 1995), can tolerate very low temperatures. In a previous work (Mazouni et al. 1998), we also pointed out that the taxonomic composition of the OCUs explain $70 \%$ of the variability of nutrient and oxygen fluxes at the OCU-water interface. We also found that species diversity in the OCU assemblage is correlated with high fluxes of nitrogen and oxygen, especially in spring. Flux intensity at the OCU-water interface is thus determined by both water temperature and the taxonomic composition of the assemblage.

The fluxes measured at the OCU-water interface are in accordance with those given in the literature for bivalve beds. The oxygen fluxes correspond to those presented by Zuburg \& Smaal (1993) for mussels with epifauna, and by Dankers et al. (1989), whereas the phosphate fluxes are similar to those measured in the intertidal zone by Prins \& Smaal (1994). Conversely, the ammonium fluxes recorded in our study are higher than those in the literature (Nowicki \& Nixon 1985, Boucher \& Boucher-Rodoni 1988). Furthermore, the high nitrate-nitrite flux we recorded could arise not only from animal excretion but also from nitrification processes. These fluxes are in the same range as those recorded when bivalves are cultivated on beds in which the contribution of sediments is important (Dame \& Dankers 1988, Smaal 1991, Prins \& Smaal 1994). According to Zuburg \& Smaal (1993), this sediment contribution can reach $70 \%$ of the total DIN released by bivalve beds. However, in our measurements at the OCU-water interface we cannot consider any contribution of bottom sediment, since oysters are reared on long lines suspended in the water column. Thus, we

Table 3. Benthic nutrient fluxes $\left(\mathrm{mg} \mathrm{N} \mathrm{m}^{-2} \mathrm{~d}^{-1}\right)$, oyster culture units (OCUs) nitrogen production and nitrogen requirements of primary producers in shellfish-farming Sector B in Thau lagoon

\begin{tabular}{|lccc|}
\hline Season & OCUs & Sediment & $\begin{array}{c}\text { Primary producer } \\
\text { demand }\end{array}$ \\
\hline Spring & 510 & 63 & 30 \\
Summer & 942 & 88 & 282 \\
Autumn & 570 & 50 & 41 \\
Winter & 104 & 11 & 10 \\
\hline
\end{tabular}

postulate that nitrogen production by the OCUs arose from both direct excretion by the shellfish assemblage itself (oyster and biofouling) and from organic matter remineralisation in the suspended sediments (i.e. sediment interface on the OCUs). In the water column, this high nitrogen production by the OCUs may control the availability of dissolved inorganic nitrogen (DIN) to the phytoplankton (Hammond et al. 1985, Kaspar et al. 1985, Dame \& Libes 1993).

In the shellfish sector studied, comparison of the activity of benthic nitrogen recycling and OCU production (Table 3) revealed that the OCUs always had the greatest impact on the environment. Moreover, in summer, biological activity of the OCU assemblage controls nitrogen renewal at a time when benthic fluxes are insufficient to satisfy phytoplankton nitrogen requirements (Table 3). Since watershed inputs are very low (sometimes non-existent) at this time, and primary production is based on recycled nitrogen (Souchu et al. 1997), the nutrient recycling by the OCUs may drive the primary production of the system. Fortunately, in this basin, harvesting occurs mainly in winter, when the influence of the oyster cultures on the water column is limited. However, over the past decade, the prolongation of the harvest throughout the year, with a rising trend in summer (correlated with the enhancement of tourist activities), could, in the near future, constitute a major source of perturbation for the whole ecosystem.

Given the intermediary position of the station studied with regard to other shellfish farming sectors, both from the point of view of environmental conditions (chlorophyll $a$, taxonomic richness and depth), the oysters' growth rate and density (Anonymous 1994), the rate of biofouling (Lamy 1996), and the intensity of nutrient fluxes, in particular during the summer (Mazouni 1995), we propose a rough extrapolation of our results to the lagoon as a whole. Although such calculations can at best offer an approximate idea of the scale of the potential impact of oyster cultures on nutrient renewal in the water column, they do provide a basis for comparison with the estimation of Picot et al. (1992). On the sole basis of oyster excretion rate, these authors estimated a DIN production by oyster cultures of $10^{7} \mathrm{~mol} \mathrm{yr}^{-1}$, whereas the present study on the whole assemblage (oysters and biofouling organisms) indicates an annual DIN production capacity in the order of $2 \times 10^{7} \mathrm{~mol} \mathrm{yr}^{-1}$. In a context where nitrogen is a limiting factor for primary production (Vaquer et al. 1997), this result emphasizes the fact that studies of the impact of oyster cultures cannot be limited to the cultured species, but must take into account the biofouling community as well. However, in order to quantify more precisely the impact of oyster cultures on nitrogen renewal on the scale of the whole Thau lagoon, 
further investigations are needed on the spatial variability of nutrient fluxes at the OCU-water interface. They will constitute the next step of our work.

Acknowledgements. We wish to thank the 4 anonymous referees for their constructive comments and suggestions and C. Juge for the illustrations. This work was financed by IFREMER and was included in the PNOC-OXYTHAU programme.

\section{LITERATURE CITED}

Agius C, Schembri PJ, Jaccarini V (1977) A preliminary report on organisms fouling oyster cultures in Malte (central Mediterranean) Mem Biol Mar Ocean 6(3-4):51-59

Alpine AE, Cloern JE (1992) Trophic interactions and direct physical effects control phytoplankton biomass and production in an estuary. Limnol Oceanogr 37:946-955

Anonymous (1994) Réseau REMORA, réseau de suivi de la croissance de l'huître creuse sur les côtes Françaises. Littaye-Mariette A (ed), Ifremer Editions, Nantes, p 1-29

Arakawa KY (1990) Competitors and fouling organisms in the hanging culture of the Pacific oyster Crassostrea gigas (Thunberg). Mar Behav Physiol 17:67-94

Boucher G, Boucher-Rodoni R (1988) In situ measurement of respiratory metabolism and nitrogen fluxes at the interface of oyster beds. Mar Ecol Prog Ser 44:229-238

Bougrier S, Geairon P, Deslous-Paoli JM, Bacher C, Jonquières G (1995) Allometric relationship and effects of température on clearance rate and oxygen consumption of Crassostrea gigas (Thunberg). Aquaculture 314:143-154

Boynton WR, Kemp WM, Osborne CG (1980) Nutrient fluxes across the sediment-water interface in the turbid zone of a coastal plain estuary. In: Kennedy VS (ed) Estuarine perspectives. Academic Press, New York, p 515-532

Branch GM (1984) Competition between marine organisms: ecological and evolutionary implications. Oceanogr Mar Biol Annu Rev 22:429-593

Chessel D, Hanafi H (1996) Analyses de la co-inertie de Knuages de points. Revue Statist Appl 44 (2):35-60

Cloern JE (1982) Does the benthos control phytoplankton biomass in south San Francisco Bay? Mar Ecol Prog Ser 9: 191-202

Courties C, Vaquer A, Troussellier M, Lautier J, CrétiennotDinet MJ, Neveux J, Machado C, Claustre H (1994) Smallest eukariotic organism. Nature 370: p 255

Dalby JE, Young CM (1993) Variable effects of ascidian competitors on oysters in a Florida epifaunal community. J Exp Mar Biol Ecol 167:47-57

Dame RF (1993) The role of bivalve filter feeder material fluxes in estuarine ecosystems. NATO ASI Ser G 33: 245-269

Dame RF, Dankers N (1988) Uptake and release of materials by a Wadden Sea mussel bed. J Exp Mar Biol Ecol 118: 207-216

Dame RF, Libes S (1993) Oyster reefs and nutrient retention in tidal creeks. J Exp Mar Biol Ecol 17:251-258

Dame RF, Spurrier JD, Wolawer TG (1989) Carbon, nitrogen and phosphorus processing by an oyster reef. Mar Ecol Prog Ser 54:249-256

Dame R, Dankers N, Prins T, Jongsma H, Smaal A (1991) The influence of mussel beds on nutrients in the Western Sea and Eastern Scheldt estuaries. Estuaries 14:130-138

Dankers N, Dame R, Kersting K (1989) The oxgen consumption of mussel beds in the Dutch Wadden Sea. Sci Mar 52: $473-476$
David A (1970) Relations trophiques entre le plancton, les huîtres d'élevage et les ciones épibiontes (étang de Thau). Thesis, Université Aix-Marseille II, Marseille

Dean TA, Hurd LE (1980) Development in an estuarine fouling community: the influence of early colonists on late arrivals. Oecologia 46:295-301

Dolédec S, Chessel D (1994) Co-inertia analysis: an alternative method for studying species-environment relationships. Freshw Biol 31:277-294

Escoffier B, Pagès J (1994) Multiple factor analysis (AFMULT package). Computational Statist Data Analysis 18:121-140

Fiala-Médioni A (1973) Ethologie alimentaire d'invertébrés benthiques filtreurs (ascidies). I. Dispositif expérimental. Taux de filtration et de digestion chez Phallusia mammillata. Mar Biol 23:137-145

Fiala-Médioni A (1974) Ethologie alimentaire d'invertébrés benthiques filtreurs (ascidies). II. Variations des taux de filtration et de digestion en fonction de l'espèce. Mar Biol 28:199-206

Fiala-Médioni A (1978) Filter-feeding ethology of benthic invertebrates (ascidians). IV. Pumping rate, filtration rate, filtration efficiency. Mar Biol 48:243-249

Frontier S, Pichot-Viale D (1991) Ecosystèmes: structure, fonctionnement, évolution. Colln Ecol (Paris) 21:1-392

Grassle J, Grassle JP (1974) Opportunistic life histories and genetic systems in marine benthic polychaetes. J Mar Res 32:253-284

Grenz C, Hermin MN, Baudinet D, Daumas R (1990) In situ biochemical and bacterial variation of sediments enriched with mussel biodeposits. Hydrobiologia 207:153-160

Hammond DE, Fuller C, Harmon D, Hartan B, Korosec M, Miller LG, Rea R, Warren S, Berelson W, Hager SW (1985) Benthic fluxes in San Francisco Bay. Hydrobiologia 129: 69-90

Hatcher A, Grant J, Schofiled B (1994) Effect of suspended mussel culture Mytilus spp. on sedimentation, benthic respiration and sediment nutrient dynamics in a coastal bay. Mar Ecol Prog Ser 115:219-235

Haury J, Baglinière JL, Cassou AI, Maisse G (1995) Analysis of spatial and temporal organisation in a salmonid brook in relation to physical factors and macrophytic vegetation. Hydrobiologia 300/301:269-277

Jackson JBC (1983) Biological determinants of present and past sessile animal distributions. In: Tevesz MJS, Mc Cail PL (eds) Biotic interactions in recent and fossil benthic communities, Plenum Press, New York, p 39-120

Jarry V, Fiala M, Frisoni GF, Jacques G, Neveux J, Panouse M (1990) The spatial distribution of phytoplankton in a Mediterranean lagoon (Etang de Thau). Oceanol Acta 13: 503-512

Jørgensen CB (1966) Biology of suspension feeding. Pergamon Press, London

Jørgensen CB, Goldberg ED (1953) Particle filtration in some ascidians and lamellibranchs. Biol Bull 105:477-489

Jørgensen CB, Kiørboe T, Mohlenberg F, Riisgård HU (1984) Ciliary and mucus-net filter feeding with special reference to fluid mechanical characteristics. Mar Ecol Prog Ser 15: 283-292

Kaspar HF, Gillespie PA, Boyer IC, MacKenzie AL (1985) Effects of mussel aquaculture on the nitrogen cycle and benthic communities in Kenepuru Sound, Marlborough Sounds, New Zealand. Mar Biol 85:127-136

Koroleff F (1969) Direct determination of ammonia in natural waters as indophenol blue. Int Counc Explor Sea, Comm Meet C 9:1-6

Kuzuki Y (1977) Retention of small particles by the gills of the japanese oyster. Bull Jpn Soc Sci Fish 43:1391-1396 
Lamy N (1996) Organisation, structure et dynamique des peuplements macrobenthiques d'une table conchylicole de l'étang de Thau (Hérault, France). Thesis, Université Montpellier II, Montpellier

Lesser MP, Shumway SE, Cucci T, Smith J (1992) Impact of fouling organisms on mussel rope culture: interspecific competition for food among suspension-feeding invertebrates. J Exp Mar Biol Ecol 165:91-102

Lorensen CJ (1966) A method for the continuous measurement of in vivo chlorophyll concentration. Deep-Sea Res 13:223-227

Mazouni N (1995) Etude in situ de l'influence des élevages ostréicoles sur le fonctionnement d'un ecosystème lagunaire méditerraneén. Thesis, Université Aix-Marseille II

Mazouni N, Courties C, Deslous-Paoli JM, Vaquer A (1992) Phytoplanktonic size spectrum modifications induced by shellfish cultures in Thau lagoon. Congrès de cytométrie en flux et de cytométrie en image, Montpellier (France), 2-4 December 1992

Mazouni N, Gaertner JC, Deslous-Paoli JM, Landrein S, Geringer d'Oedenberg M (1996) Nutrient and oxygen exchanges at the water-sediment interface in a shellfish farming lagoon (Thau, France). J Exp Mar Biol Ecol 203: 92-113

Mazouni N, Gaertner JC, Deslous-Paoli JM (1998) Influence of oyster culture on water column characteristics in a coastal lagoon (Thau, France). Hydrobiologia 373/374:149-156

Millet B (1989) Fonctionnement hydrodynamique du basin de Thau. Validation d'un modèle numérique de circulation (programme ECOTHAU). Oceanol Acta 12:37-46

Monniot F (1979) Mise en évidence d'un filtre 'micropore' naturel chez les Ascidiacea. CR Hebd Séanc Acad Sci Paris 289:927-929

Murphy RC, Kremer JN (1985) Bivalve contribution to benthic metabolism in a California lagoon. Estuaries 8:330-341

Nowicki BL, Nixon SW (1985) Benthic community metabolism in a coastal lagoon ecosystem. Mar Ecol Prog Ser 22:21-30

Osman RW, Whitlatch RB, Zajac RN (1989) Effects of resident species on recruitment into a community: larval settlement versus post-settlement mortality in the oyster Crassostrea virginica. Mar Ecol Prog Ser 54:61-73

Outin V (1990) Ecophysiologie de l'huitre Crassostrea gigas (Thunberg) en milieu naturel. Rôle des populations d'une lagune méditerranéenne dans les transferts des matières particulaire et dissoute. Thesis, Université Paris VI, Paris

Petersen JK, Svane I (1995) Larval dispersal in the ascidian Ciona intestinalis (L.). Evidence for a closed population. J Exp Mar Biol Ecol 186:89-102

Petersen JK, Schou O, Thor P (1997) In situ growth of the ascidian Ciona intestinalis (L.) and the blue mussel Mytilus edulis in an eelgrass meadow. J Exp Mar Biol Ecol 218:1-11

Picot B, Pena G, Casellas C, Bondon D, Bontoux J (1992) Interpretation of the seasonal variations of nutrients in a Mediterranean lagoon: étang de Thau. Hydrobiologia 207:105-114

Prins TC, Smaal AC (1990) Benthic-pelagic coupling: the release of inorganic nutrients by an intertidal bed of Mytilus edulis. In: Barnes M, Gibson RN (eds) Trophic relationship in the marine environment. Aberdeen University Press, Aberdeen, p 89-103

Editorial responsibility: Otto Kinne (Editor), Oldendorf/Luhe, Germany
Prins TC, Smaal AC (1994) The role of the blue mussel Mytilus edulis in the cycling of nutrients in the Oostershelde estuary (The Netherlands). Hydrobiologia 282/ 283:413-429

Randlov A, Riisgård HU (1979) Efficiency of particle retention and filtration rate in four species of ascidians. Mar Ecol Prog Ser 1:55-59

Reish DJ (1955) The relation of polychaetous annelids to harbour pollution. Publ Health Rep Wash 70:1168-1174

Reiswig HM (1972) Particle feeding in natural populations of three marine demosponges. Biol Bull 141:568-591

Riisgård HU, Christensen PB, Olesen NJ, Petersen JK, Moller MM, Andersen P (1995) Biological structure in a shallow cove (Kertinge Nor, Denmark). Control by benthic nutrient fluxes and suspension-feeding ascidians and jellyfish. Ophelia 41:329-344

Riva A, Massé H (1985) Etude écophysiologique de quelques mollusques bivalves. Bases biologiques de l'Aquaculture. Act Colloques, Montpellier 1:45-62

Shumway SE (1981) Oxygen consumption in oysters: an overview. Mar Biol Lett 3:1-23

Shumway SE, Cucci TL, Newell R, Yentsch CM (1985) Particle selection, ingestion and absorption in filter-feeding bivalves. J Exp Mar Biol Ecol 91:77-92

Smaal AC (1991) The ecology and cultivation of mussels: new advances. Aquaculture 94:245-261

Sornin JM Delmas D, Deslous-Paoli JM (1987) Evolution quantitative du seston dans une claire à huîtres: relation avec la sédimentation et la biodéposition. Océanis Paris 13:531-541

Sornin JM, Collos Y, Delmas D, Feuillet-Girard M, Gouleau D (1990) Nitrogenous nutrient transfers in oyster ponds: role of sediment in deferred primary production. Mar Ecol Prog Ser 68:15-22

Souchu P, Gasc A, Cahet G, Vaquer A, Collos Y, Deslous-Paoli JM (1997) Biogeochemical composition of Mediterranean waters outside Thau lagoon. Estuar Coast Shelf Sci 44: 275-284

Stuart V, Klumpp DW (1984) Evidence for food-resource partitioning by kelpbed filter feeders. Mar Ecol Prog Ser $16: 27-37$

Ter Braak CJF (1987) The analysis of vegetation-environment relationships by canonical correspondance analysis. Vegetatio 69:69-77

Thioulouse J, Chessel D, Dolédec S, Oliver JM (1996) ADE-4: a multivariate analysis and graphical display software. Statistics Comput 7:75-83

Thorson G (1950) Reproduction and larval ecology of marine bottom invertebrates. Biol Rev 25:1-45

Tréguer P, Le Corre P (1975) Manuel d'analyses de sels nutritifs dans l'eau de mer. Utilisation de l'Autoanalyzer II Technicon. 2 ème édn, Laboratoire d'Océanographie Chimique, Université Bretagne Occidentale, Brest

Vaquer A, Troussellier M, Courties C, Bibent B (1997) Standing stock and dynamics of picophytoplankton in the Thau lagoon (northwest Mediterranean coast). Limnol Oceanogr 41:1821-1828

Zuburg W, Smaal AC (1993) Uptake and release of suspended and dissolved material by oyster and mussel beds in the bay of Marennes-Oléron (France). Directoraat-Generaal, Rijkswaterstaat, Netherlands (Rep)

Submitted: November 24, 1998; Accepted: March 21, 2000

Proofs received from author(s): March 13, 2001 